\title{
DVL1 wt Allele
}

National Cancer Institute

\section{Source}

National Cancer Institute. DVL1 wt Allele. NCI Thesaurus. Code C114515.

Human DVL1 wild-type allele is located in the vicinity of $1 \mathrm{p} 36$ and is approximately $14 \mathrm{~kb}$ in length. This allele, which encodes segment polarity protein dishevelled homolog DVL-1 protein, is involved in Wnt signaling. 